\title{
Synergistic Effects of Halide Ions and Acacia senegal Gum on the Corrosion Inhibition of Mild Steel in Sulfuric Acid Solution
}

\author{
Jovine Emmanuel $^{1^{*}}$ and Joseph Buchweishaija ${ }^{2}$ \\ ${ }^{I}$ Chemistry Department, Mkwawa University College of Education, P. O. Box 2513, Iringa, \\ Tanzania.E-mail: jovineemma2007@yahoo.co.uk \\ ${ }^{2}$ Chemistry Department, University of Dar es Salaam, P. O. Box 35061, Dar es Salaam Tanzania. \\ E-mail: jbuchwa@yahoo.com \\ *Corresponding author \\ Received 9 Feb 2021, Revised 26 Apr 2021, Accepted 27 Apr 2021, Published May 2021 \\ DOI: https://dx.doi.org/10.4314/tjs.v47i2.24
}

\begin{abstract}
The synergistic effects of halide ions, $\mathrm{Br}^{-}$and $\mathrm{I}^{-}$and Acacia senegal gum exudates on the corrosion inhibition of mild steel in $0.5 \mathrm{M}$ sulfuric acid solution has been investigated by potentiodynamic polarization measurements and electrochemical impedance spectroscopy techniques. Results showed that Acacia senegal gum exudate moderately reduces the corrosion rate of mild steel. The inhibition efficiencies on mild steel electrodes increased with increase in gum exudate concentrations up to $300 \mathrm{ppm}$, corresponding to the inhibition efficiency of about $43 \%$ and its inhibition efficiency increased up to $81.6 \%$ with addition of halide ions due to synergistic effects. The enhancement effect of the halide ions was higher with iodide than with bromide ions. The synergism parameter, $S_{l}$, evaluated was greater than unity, consistent with synergistic effect. The adsorption of Acacia senegal gum on the mild steel surface obeyed Langmuir's adsorption isotherm. The results obtained, i.e., corrosion rates of mild steel, inhibition efficiencies of Acacia senegal gum exudates and the synergistic effects of Acacia senegal gum exudates and halides from polarization and impedance measurements were in good agreement.
\end{abstract}

Keywords: corrosion, inhibition, mild steel, synergistic effect, Acacia senegal, gum exudate.

\section{Introduction}

Corrosion is a major problem in most industries across the world, which diversely affects the performance of materials in applications (Eddy 2009). Failures due to corrosion effects have significant economic consequences in terms of repair and replacement costs, loss of production, and can have very serious implications on both safety and environmental pollution. Thus, the control of corrosion of metals is an important activity of technical, economical, health and environmental importance. For that reasons, the search for new and efficient corrosion inhibition approaches have become a necessity in order to secure metallic materials against corrosion.

Corrosion inhibition of mild steel has gained much interests because it is widely used as a construction and structural material in many fields of engineering due to its excellent mechanical properties and low costs (Abu-Dalo et al. 2012). Despite its relatively limited corrosion resistance when in contact with corrosive media, mild steel is still a material of choice in various applications especially in the media where acids are widely used for various applications such as acid pickling, cleaning, descaling and oil well acidizing (Chaudhary et al. 2007). One of the techniques to protect this 
cheap and construction engineering material from corrosion is the use of corrosion inhibitors to control metal dissolution in the systems and reduce its corrosion rate when in contact with aggressive acidic solutions (AbuDalo et al. 2012, El-Maksoud 2008). The use of natural organic products as corrosion inhibitors have been widely reported by several authors (Buchweishaija and Mhinzi 2008, Ebenso et al. 2008, Eddy 2009, Abu-Dalo et al. 2012, Al-Otaibi et al. 2014). However, it has been reported that the presence of halide ions in solution stabilize the adsorption of some of the organic cations leading to improved inhibition efficiency (Obot 2009, Umoren et al. 2008, Shaju et al. 2012). The investigation on synergism of these halide ions has become an important phenomenon and serves as a basis for modern corrosion inhibitor formulation. There are reports that halides inhibit the corrosion processes of some metals in strong acids (Umoren et al. 2008, Shaju et al. 2012). This effect depends on the ionic size and charge, the electrostatic field set up by the negative charge of the anion on adsorption sites and the nature and concentrations of the halide ions. There are reports explaining the difference in the actions of the halides, which depend on the atomic radii and/or the electronegativity (El-Maksoud 2008, Umoren et al. 2008). Obot reported that the inhibition effect of halide ions in combination with inhibitor follow the trend $\mathrm{I}^{-}>\mathrm{Br}^{-}>\mathrm{Cl}^{-}$(Obot 2009). It is argued that the greater influence of the iodide ion is often associated to its large ionic radius, high hydrophobicity and low electronegativity, when compared to other halide ions (Obot 2009). To this end, various concentrations of halides, $\mathrm{KBr}$ and $\mathrm{KI}$, were considered for synergistic effects studies on the performance of Acacia senegal gum. However, mild steel corrosion inhibition by Acacia senegal gum and halides ions have not been extensively explored. In the present study, results pertaining to the synergistic effects of Acacia senegal gum and halide ions on the corrosion inhibition of mild steel in $0.5 \mathrm{M}$ sulfuric acid solution at $35^{\circ} \mathrm{C}$ are reported.

\section{Materials and Methods Experimental}

The investigation was carried out in a conventional three electrodes system $(50 \mathrm{ml})$ Pyrex glass cell in the Chemistry Department, University of Dar es Salaam. Mild steel was used as a working electrode, a saturated calomel electrode (SCE) and platinum electrode as a reference and counter electrode, respectively. The mild steel electrode used in this study had the following composition (wt $\%), \mathrm{C}$ (1.62), Si (1.31), Al (1.05), Mn (0.47), $\mathrm{Cr}(0.17), \mathrm{Ni}(0.03), \mathrm{Cu}(0.41), \mathrm{V}(0.006)$ and $\mathrm{Fe}$ (94.914). The electrodes were machined into discs enough to be mounted into Teflon holder exposing only a surface area of $0.2 \mathrm{~cm}^{2}$. All working electrodes were wet abraded with 320 to 800 grit silicon carbide papers then polished with diamond paste to achieve mirror finishing surfaces from $15 \mu \mathrm{m}$ to $1 \mu \mathrm{m}$ by using LaboPol-5 grinding/polishing machine. The specimens were then ultrasonically degreased in acetone, rinsed with methyl alcohol, dried in air at room temperature and immediately stored in a desiccator. All chemicals used were of analytical grade and were used without further purification. All solutions were prepared using distilled water. These included concentrated sulfuric acid (96\%) supplied by Panreal Quimica SA, methyl alcohol (assay 99.9\%) by Carlo Erba, Strada Rivoltana, potassium iodide (assay 99.8\%) analytical reagent by Techno Pharmchem, Bahadurgarh, India and potassium bromide (assay $99.5 \%$ ) by MB, England. The corrosive medium was prepared by diluting concentrated sulfuric acid with distilled water to $0.5 \mathrm{M} \mathrm{H}_{2} \mathrm{SO}_{4}$. The halides used were $\mathrm{KBr}$ and $\mathrm{KI}$ at concentrations ranging from 0.01 to $0.1 \mathrm{M}$. The corrosion inhibitor tested in this study was a commercial Acacia senegal gum supplied by BDH Laboratory Chemicals Division, Poole, England. The finely ground Acacia senegal gum powder was dissolved in distilled water to form solutions based on ppm (parts per million) units. The concentrations of the gum ranged from 100 to $600 \mathrm{ppm}$.

The prepared electrodes were mounted on the rotating disc electrode system and 
introduced in the glass cell containing the test solution ready for electrochemical measurements. Experiments were performed at a solution temperature condition of $35^{\circ} \mathrm{C}$ and the $\mathrm{pH}$ of the test solution was $0.7 \pm 0.2$ without and with various inhibitor concentrations. The $\mathrm{pH}$ used reflects the practical settings where sulfuric acid is extensively used to remove deposits and in acid pickling operations for scale removal. The same procedures were followed for each experiment. Halides solution of concentrations ranging between 0.01 to $0.1 \mathrm{M}$ of $\mathrm{KBr}$ and $\mathrm{KI}$ were prepared and tested on mild steel corrosion inhibition in $0.5 \mathrm{M}$ sulfuric acid media without and with 300 ppm Acacia senegal gum inhibitor at $35{ }^{\circ} \mathrm{C}$. Electrochemical impedance spectroscopy and potentiodynamic polarization techniques were employed. The effects of the halides, $\mathrm{Br}^{-}$and $\mathrm{I}^{-}$ , on the efficiency of corrosion protection of Acacia senegal gum was investigated. The solution temperature was controlled by passing thermostated water through the jacket around the cell via the tubes, which drained water from the thermostat bath to the cell and back to the thermostat continuously throughout the experiment. Surface properties (morphology) of both inhibited and uninhibited mild steel specimens were assessed using optical microscopy (Ziess Axioskop 40).

All electrochemical experiments were performed using the Voltlab 80 PGZ402 potensiostat. The working electrode was left immersed in the test solution under Open Circuit Potential (OCP) for 30 minutes to attain a steady state OCP value before the measurements were conducted. Both cathodic and anodic potentiodynamic polarization curves were recorded over the potential range from -600 to $-400 \mathrm{mV}$ vs SCE at a scan rate of $1.0 \mathrm{mV} / \mathrm{s}$. The linear Tafel segments of anodic and cathodic curves were extrapolated to corrosion potential, $E_{\text {corr }}$, to obtain the corrosion current density ( $\left.i_{\text {corr }}\right)$. Electrochemical impedance spectroscopy (EIS) measurements were recorded at OPC over the frequency range $100 \mathrm{kHz}$ down to $0.1 \mathrm{~Hz}$ at an amplitude of $10 \mathrm{mV}$ and scan rate of 10 points per decade (Khan et al. 2015, Kulandai Therese and Vasudha 2015, Martinez and Stern 2002). The Nyquist curves of the impedance data were analyzed using the Microsoft Office Excel. The charge transfer resistance was obtained from the diameter of the semicircle of the Nyquist plots.

\section{Results and Discussion}

Typical polarization curves recorded on the mild steel in $0.5 \mathrm{M} \mathrm{H}_{2} \mathrm{SO}_{4}$ acid in the absence and presence of $300 \mathrm{ppm}$ and $400 \mathrm{ppm}$ Acacia senegal gum are shown in Figure 1. The data obtained from these polarization curves by Tafel extrapolations are presented in Table 1. These include; Tafel constants $\left(b_{\mathrm{a}}\right.$ and $b_{\mathrm{c}}$ ), corrosion potentials $\left(\mathrm{E}_{\mathrm{corr}}\right)$ and corrosion current densities $\left(i_{\text {corr }}\right)$. Other values shown in the same table are the calculated corrosion rates $\left(R_{\text {corr }}\right)$, inhibition efficiencies $\left(I_{\mathrm{eff}}\right)$ and the $R_{\text {corr }}$ values in millimeters per year (mmpy). The corrosion current density reduction is more pronounced at a concentration of $300 \mathrm{ppm}$ of Acacia senegal gum (Figure 1 and Table 1). However, as the concentration of the gum exceeds $300 \mathrm{ppm}$ an abrupt increase of corrosion current densities was observed indicating a decline in the mild steel corrosion inhibition by Acacia senegal gum exudates. 
Tanz. J. Sci. Vol. 47(2) 2021

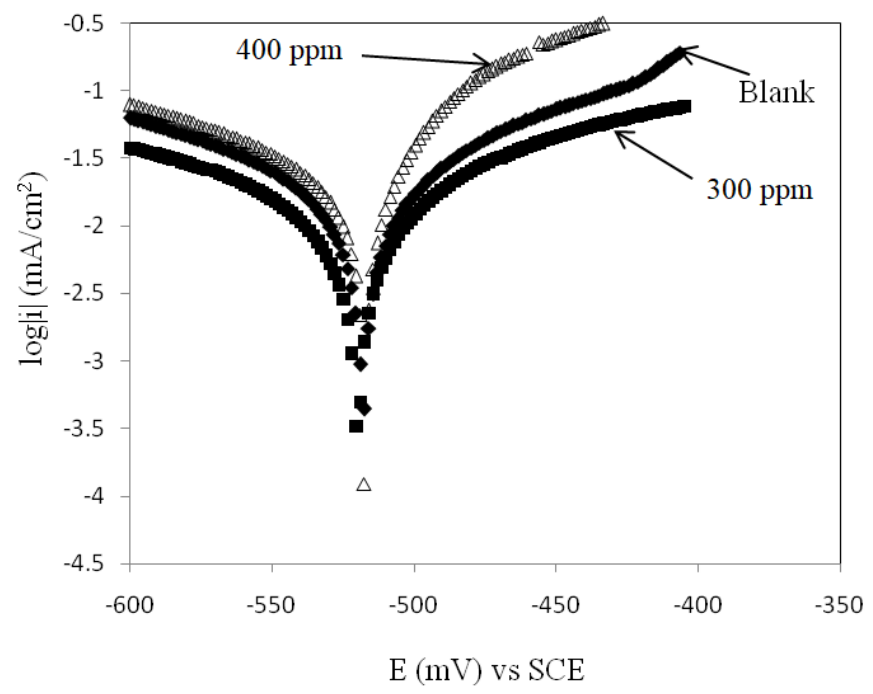

Figure 1: Polarization curves for mild steel electrodes in the absence and presence of 300 and 400 ppm Acacia senegal gum in $0.5 \mathrm{M} \mathrm{H}_{2} \mathrm{SO}_{4}$ solutions ( $\mathrm{pH} 0.7$ ) at $35^{\circ} \mathrm{C}$.

Table 1: Potentiodynamic polarization parameters of mild steel electrodes in $0.5 \mathrm{M} \mathrm{H}_{2} \mathrm{SO}_{4}$ solutions ( $\mathrm{pH} 0.7)$ at $35{ }^{\circ} \mathrm{C}$ in the absence and presence of various concentrations of Acacia senegal gum

\begin{tabular}{ccccccc}
\hline $\mathrm{C}_{\text {inh }}(\mathrm{ppm})$ & $\begin{array}{c}\mathrm{b}_{\mathrm{a}} \\
(\mathrm{mV} / \mathrm{dec})\end{array}$ & $\begin{array}{c}\mathrm{b}_{\mathrm{c}} \\
(\mathrm{mV} / \mathrm{dec})\end{array}$ & $\begin{array}{c}\mathrm{E}_{\text {corr }} \\
(\mathrm{mV} \text { vs SCE })\end{array}$ & $\begin{array}{c}\mathrm{i}_{\text {corr }} \\
\left(\mathrm{mA} / \mathrm{cm}^{2}\right)\end{array}$ & $\begin{array}{c}\mathrm{R}_{\text {corr }} \\
(\mathrm{mmpy})\end{array}$ & $\begin{array}{c}\mathrm{I}_{\text {eff }} \\
(\%)\end{array}$ \\
\hline Blank & 14.4 & -22.2 & -520.5 & 0.003 & $3.5 \times 10^{-8}$ & - \\
100 & 16.2 & -21.8 & -515.2 & 0.0025 & $2.9 \times 10^{-8}$ & 16.7 \\
200 & 16.4 & -18.5 & -522.9 & 0.002 & $2.3 \times 10^{-8}$ & 33.33 \\
300 & 18.1 & -20 & -522.5 & 0.0017 & $1.9 \times 10^{-8}$ & 43.33 \\
400 & 19.3 & -25 & -520.5 & 0.005 & $5.8 \times 10^{-8}$ & 33.34 \\
500 & 21.2 & -30 & -521.7 & 0.0026 & $6.9 \times 10^{-8}$ & 13.33 \\
600 & 30 & -35 & -532.2 & 0.0023 & $5.8 \times 10^{-8}$ & 23.33 \\
\hline
\end{tabular}

The maximum of about $43 \%$ corrosion inhibitor efficiency was achieved by the addition of $300 \mathrm{ppm}$ of Acacia senegal gum. It has been oberved that the corrosion inhibition efficiency decreases beyond $300 \mathrm{ppm}$, an indication that $300 \mathrm{ppm}$ of Acacia senegal gum exudate is the optimal concentration. The corrosion potentials $\left(\mathrm{E}_{\mathrm{corr}}\right)$ values are more or less constant at all the concentrations of Acacia senegal gum applied. These performances obtained are quite low when compared to previous studies (Buchweishaija and Mhinzi 2008) on the corrosion inhibition effect of
Acacia seyal var. seyal who observed that the percentage inhibition increases with increasing the concentrations of the gum. The inhibitor efficiency above $95 \%$ with gum concentration $\geq 400 \mathrm{ppm}$ at room temperature was registered. In a different study (Alsabagh et al. 2015) on the corrosion inhibition of mild steel by green tea extract as inhibitor in sulfuric acid solution, the maximum inhibition efficiency of $71.65 \%$ was achieved at an inhibitor concentration of about 500 ppm. Other studies have also shown that plant extracts inhibitors, reasonably inhibit mild steel corrosion in acidic media and the 
inhibition efficiency increses with increase in the concentrations of inhibitor (Eddy 2009a, Eddy 2009b, El-Etre and El-Tantawy 2006, Gupta and Singh 2009, Noor 2007, Obot et al. 2012, Odiongenyi et al. 2009, Oguzie 2008, Olusegun et al. 2004). Impedance data in the

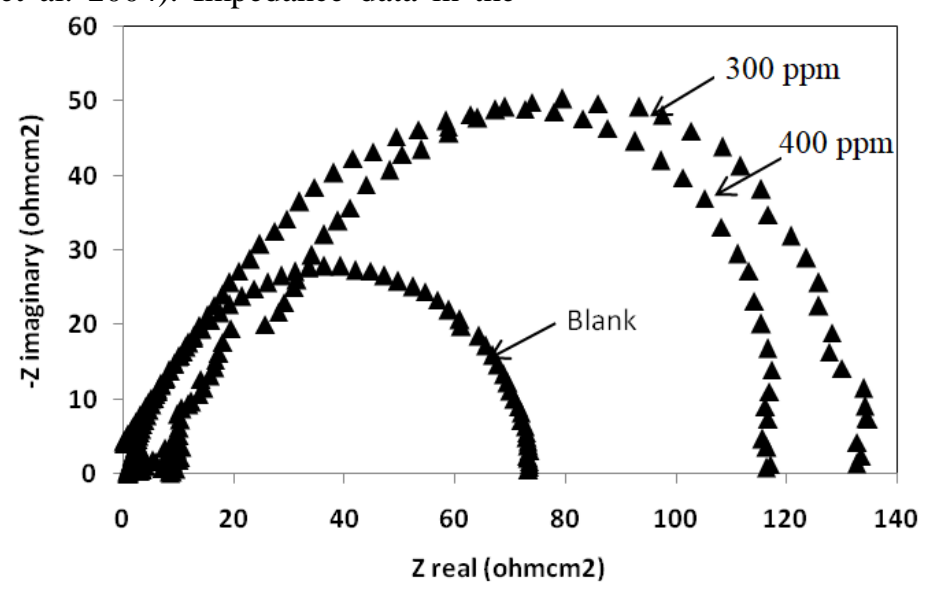

Figure 2: Impedance plot in Nyquist format for mild steel electrodes in $0.5 \mathrm{M} \mathrm{H}_{2} \mathrm{SO}_{4}$ solutions without and with $300 \mathrm{ppm}$ and $400 \mathrm{ppm}$ concentrations of Acacia senegal gum (pH $0.7)$ at $35^{\circ} \mathrm{C}$.

It is seen from Figure 2 that the spectra are characterized by depressed semicircles whose sizes increased as the concentrations of Acacia senegal gum increased. However, it has been observed that as the concentrations of Acacia senegal gum exceed $300 \mathrm{ppm}$, the sizes of the semicircles start to decline, an indication of the decrease in the inhibitor performance as the concentrations increase above $300 \mathrm{ppm}$. This suggests that less inhibitor is adsorbed and small protective film is formed on the metal surface when the gum exceeds $300 \mathrm{ppm}$, giving rise to a low corrosion inhibition efficiency. It was found in this study that $300 \mathrm{ppm}$ is the optimum inhibitor concentration which resulted into the maximum protection of mild steel against corrosion. These results are not in agreement with previous findings (Buchweishaija and Mhinzi 2008) using Acacia seyal var. seyal inhibitor where the inhibition efficiency increased monotonically with increasing gum concentrations at $30{ }^{\circ} \mathrm{C}$. Reports on an increase
Nyquist format for mild steel in $0.5 \mathrm{M} \mathrm{H}_{2} \mathrm{SO}_{4}$ in the absence and presence of $300 \mathrm{ppm}$ and $400 \mathrm{ppm}$ Acacia senegal gum at $35^{\circ} \mathrm{C}$ are presented in Figure 2. of corrosion inhibition efficiencies with increasing inhibitor concentrations are available (Obot et al. 2012, Obot 2009, Shaju et al. 2012). The impedance spectra in Nyquist plots format were analysed by fitting the experimental data to a simple equivalent circuit model. The values of elements fitted to the model are summarized in Table 2. These include charge transfer resistance $\left(R_{\mathrm{ct}}\right)$, dimensionless value $(\mathrm{n})$ and calculated double layer capacitance $\left(C_{\mathrm{dl}}\right)$. Other parameters include the reciprocal of charge transfer resistance $\left(R_{\mathrm{ct}}{ }^{-1}\right)$ and calculated corrosion inhibition efficiencies $\left(I_{\text {eff }}\right)$. The corrosion current density values were estimated as being equal to the reciprocal of charge transfer resistance by using the modified Stern-Geary relation (Buchweishaija 1997). The impedance results are in good agreement with polarization results. Both techniques have shown that Acacia senegal gum works best at a concentration of $300 \mathrm{ppm}$. The charge transfer resistance increases with increase in the concentrations of 
Acacia senegal gum up to $300 \mathrm{ppm}$ beyond which it is observed to decrease (Figure 2), the inhibition efficiency follows a similar trend suggesting that $300 \mathrm{ppm}$ of Acacia senegal gum is the optimal inhibitor concentration. A similar trend has been reported (Eddy and Ebenso 2008) on the inhibitive properties of Musa sapientum peels extracts as inhibitor for mild steel in $\mathrm{H}_{2} \mathrm{SO}_{4}$. The maximum value of inhibition efficiency of $71.05 \%$ at a concentration of 0.5 $\mathrm{g} / \mathrm{L}$ was reported. It was observed that the inhibition efficiency of Musa sapientum varies with its concentration. Similar results have been reported (Orubite-Okorosaye et al. 2007) and (Buchweishaija and Mhinzi 2008). The latter reported that the percentage inhibition efficiency of Acacia seyal var seyal gum increased to a value greater than $95 \%$ at gum concentration $\geq$ $400 \mathrm{ppm}$.

Table 2: Electrochemical Impedance parameters measurements on mild steel electrodes in $0.5 \mathrm{M}$ $\mathrm{H}_{2} \mathrm{SO}_{4}$ solutions ( $\mathrm{pH} 0.7$ ) at $35{ }^{\circ} \mathrm{C}$ in absence and presence of various concentrations of Acacia senegal gum

\begin{tabular}{cccccc}
\hline $\mathrm{C}_{\mathrm{inh}}(\mathrm{ppm})$ & $\mathrm{R}_{\mathrm{ct}}\left(\Omega \mathrm{cm}^{2}\right)$ & $\mathrm{n}$ & $\mathrm{C}_{\mathrm{dl}}\left(\mu \mathrm{Fcm}^{2}\right)$ & $\mathrm{R}_{\mathrm{ct}}^{-1}\left(\Omega^{-1} \mathrm{~cm}^{-2}\right)$ & $\mathrm{I}_{\text {eff }}(\%)$ \\
\hline Blank & 80.0 & 0.998 & 152.5 & 0.0125 & - \\
100 & 110.0 & 0.993 & 124.7 & 0.0090 & 28.0 \\
200 & 115.0 & 0.901 & 102.8 & 0.0086 & 31.2 \\
300 & 130.0 & 0.990 & 96.7 & 0.0076 & 39.2 \\
400 & 118.0 & 0.965 & 158.1 & 0.0084 & 32.8 \\
500 & 100.0 & 0.976 & 199.7 & 0.0100 & 20.0 \\
600 & 111.5 & 0.987 & 243.3 & 0.0089 & 28.8 \\
\hline
\end{tabular}

These results show that Acacia senegal gum exhibits a moderate mild steel corrosion inhibition efficiency. The test showed that addition of $\mathrm{KBr}$ and $\mathrm{KI}$ into the system resulted into further decrease in the corrosion rate for mild steel in acidic solutions, Table 3. An increase in charge transfer resistance and reduction in corrosion current density were recorded at $0.08 \mathrm{M}$ concentration of both $\mathrm{KBr}$ and KI. Thus, $0.08 \mathrm{M}$ of $\mathrm{KBr}$ and $\mathrm{KI}$ solutions were used for synergistic studies of halide ions with Acacia senegal gum exudate inhibitor on mild steel corrosion inhibition in $0.5 \mathrm{M} \mathrm{H}_{2} \mathrm{SO}_{4}$ solution. Synergistic studies of the halides were performed with $300 \mathrm{ppm}$ of Acacia senegal gum and $0.08 \mathrm{M} \mathrm{KBr}$ and KI. Potentiodynamic polarization and electrochemical impedance techniques were used (Figure 3 and 4). 


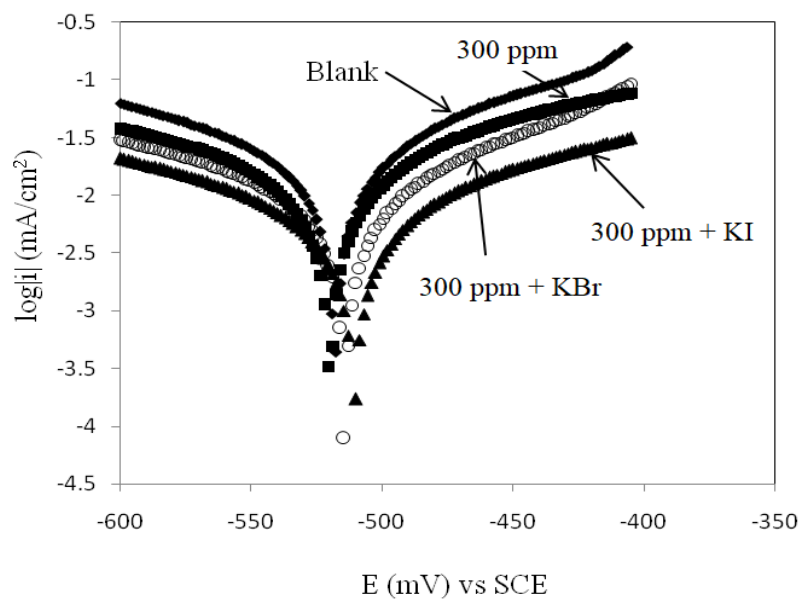

Figure 3: Polarization curves for mild steel electrodes in the presence of $300 \mathrm{ppm}$ Acacia senegal gum $+0.08 \mathrm{M}$ halide ions $(\mathrm{KBr}$ and $\mathrm{KI})$ at $35^{\circ} \mathrm{C}$.

Polarization curves (Figure 3) show a systematic pattern after addition of $0.08 \mathrm{M}$ of halides in $300 \mathrm{ppm}$ Acacia senegal gum leading into an improvement of the corrosion inhibition of mild steel in $0.5 \mathrm{M} \mathrm{H}_{2} \mathrm{SO}_{4}$ solutions. Electrochemical parameters obtained from these curves through extrapolation of anodic and cathodic Tafel lines are shown in Table 3. The parameters include Tafel constants $\left(b_{a}\right.$ and $\left.b_{c}\right)$, corrosion potentials $\left(\mathrm{E}_{\text {corr }}\right)$ and corrosion current densities ( $\left.\mathrm{i}_{\text {corr }}\right)$. The calculated corrosion rates $\left(\mathrm{R}_{\text {corr }}\right)$ and corrosion inhibition efficiencies $\left(\mathrm{I}_{\mathrm{eff}}\right)$ are also included. Results show that, addition of 300 ppm Acacia senegal gum with $0.08 \mathrm{M}$ of halides $(\mathrm{KBr}$ and $\mathrm{KI})$ reduces the values of corrosion current density from the blank value of $0.0030 \mathrm{~mA} / \mathrm{cm}^{2}$ to $0.0016 \mathrm{~mA} / \mathrm{cm}^{2}$ for $\mathrm{KBr}$ and $0.0007 \mathrm{~mA} / \mathrm{cm}^{2}$ for KI corresponding to corrosion inhibition effeciency of $46.7 \%$ and $76.7 \%$, respectively, when comapared with the inhibition efficiency of $43.3 \%$ for Acacia senegal gum alone at $300 \mathrm{ppm}$. The reduction in corrosion rate is enhanced more with the addition of $0.08 \mathrm{M} \mathrm{KI}$ as compared to $0.08 \mathrm{M}$ $\mathrm{KBr}$. Addition of halide salts resulted into a significant drop in both corrosion current densities and corrosion rates, implying higher corrosion inhibition efficiencies because halide ions in solution stabilize the adsorption of some of the organic cations (Obot 2009, Umoren et al. 2008, Shaju et al. 2012).

Table 3: Potentiodynamic polarization parameters of mild steel electrodes in the absence and presence of optimal concentration of Acacia senegal gum (300 ppm) and Acacia senegal gum (300 ppm) with $0.08 \mathrm{M} \mathrm{KBr}$ or $0.08 \mathrm{M} \mathrm{KI}$ in $0.5 \mathrm{M} \mathrm{H}_{2} \mathrm{SO}_{4}$ solutions (pH 0.7) at 35 ${ }^{\circ} \mathrm{C}$

\begin{tabular}{lcccccr}
\hline $\mathrm{C}_{\text {inh }}(\mathrm{ppm})$ & $\begin{array}{c}\mathrm{b}_{\mathrm{a}} \\
(\mathrm{mV} / \mathrm{dec})\end{array}$ & $\begin{array}{c}\mathrm{b}_{\mathrm{c}} \\
(\mathrm{mV} / \mathrm{dec})\end{array}$ & $\begin{array}{c}\mathrm{E}_{\text {corr }} \\
(\mathrm{mV} \text { vs SCE })\end{array}$ & $\begin{array}{c}\mathrm{i}_{\text {corr }} \\
\left(\mathrm{mA} / \mathrm{cm}^{2}\right)\end{array}$ & $\begin{array}{c}\mathrm{R}_{\text {corr }} \\
(\mathrm{mmpy})\end{array}$ & $\begin{array}{c}\mathrm{I}_{\text {eff }} \\
(\%)\end{array}$ \\
\hline Blank & 14.4 & -22.2 & -520.5 & 0.0030 & $3.5 \times 10^{-8}$ & - \\
300 & 18.1 & -20.0 & -522.5 & 0.0017 & $1.9 \times 10^{-8}$ & 43.3 \\
$300+0.08 \mathrm{KBr}$ & 14.3 & -21.8 & -516.8 & 0.0016 & $1.8 \times 10^{-8}$ & 46.7 \\
$300+0.08 \mathrm{KI}$ & 23.9 & -20.6 & -513.2 & 0.0007 & $8.1 \times 10^{-9}$ & 76.7 \\
\hline
\end{tabular}


Figure 4 and Table 4 are electrochemical impedance results performed on the mild steel in aerated $0.5 \quad \mathrm{M} \mathrm{H} \mathrm{H}_{2} \mathrm{SO}_{4}$ to assess the synergistic effects of halides on the performance of Acacia senegal gum. The impedance behaviour for the mild steel electrode in the acidic solution containing 300 ppm of inhibitor together with $0.08 \mathrm{M}$ of halides at $35{ }^{\circ} \mathrm{C}$ is observed. Electrochemical parameters including; the charge transfer resistance $\left(\mathrm{R}_{\mathrm{ct}}\right)$, dimensionless value $(\mathrm{n})$ and the double layer capacitance $\left(\mathrm{C}_{\mathrm{dl}}\right)$ are also included (Table 4). The reciprocal of charge transfer resistance $\left(\mathrm{R}_{\mathrm{ct}}{ }^{-1}\right)$ and corrosion inhibition efficiencies $\left(\mathrm{I}_{\mathrm{eff}}\right)$ are also presented.

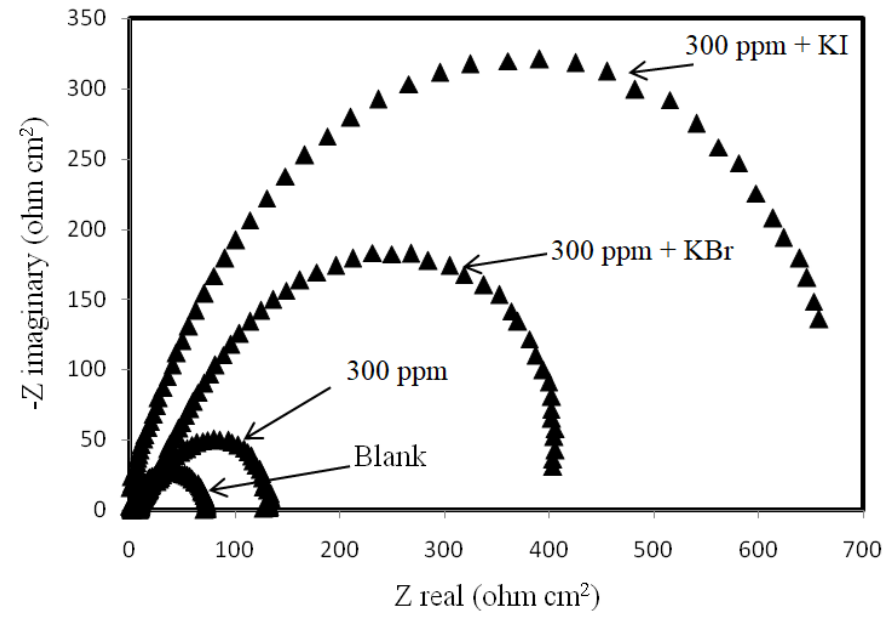

Figure 4: Impedance plot in Nyquist format for mild steel electrodes in Acacia senegal gum and Acacia senegal gum with $0.08 \mathrm{M} \mathrm{KBr}$ or $0.08 \mathrm{M} \mathrm{KI}$ in $0.5 \mathrm{M} \mathrm{H}_{2} \mathrm{SO}_{4}(\mathrm{pH} 0.7)$ at 35 ${ }^{\circ} \mathrm{C}$.

It is evident that addition of halides in the inhibitor improves its performance significantly. Addition of $0.08 \mathrm{M}$ of $\mathrm{KBr}$ and KI to the inhibitor increased the values of $R_{c t}$ from that of $300 \mathrm{ppm}$ value of $130 \Omega \mathrm{cm}^{2}$ to $403.7 \Omega \mathrm{cm}^{2}$ and $701.2 \Omega \mathrm{cm}^{2}$ for $\mathrm{KBr}$ and $\mathrm{KI}$, respectively. This corresponds to an increment in the corrosion inhibition efficiency of $29 \%$ and $42 \%$ for $\mathrm{KBr}$ and $\mathrm{KI}$, respectively. The double layer capacitance values also decreased to low values as compared to those of the blank. This is attributed to an enhanced surface coverage compared to the halide free systems.

Table 4: Electrochemical impedance parameters measurements on mild steel electrodes in $0.5 \mathrm{M}$ $\mathrm{H}_{2} \mathrm{SO}_{4}$ solution at $35{ }^{\circ} \mathrm{C}$ in absence and presence of $300 \mathrm{ppm}$ of Acacia senegal gum mixed with $0.08 \mathrm{M}$ halide ions ( $\mathrm{KBr}$ or $\mathrm{KI})$

\begin{tabular}{cccccc}
\hline$C_{\text {inh }}(\mathrm{ppm})$ & $R_{\mathrm{ct}}\left(\Omega \mathrm{cm}^{2}\right)$ & $\mathrm{n}$ & $C_{\mathrm{dl}}(\mu \mathrm{Fcm}$ & $R_{\mathrm{ct}}^{-1}\left(\Omega^{-1} \mathrm{~cm}^{-2}\right)$ & $I_{\text {eff }}(\%)$ \\
\hline Blank & 80 & 0.998 & 404.0 & 0.0125 & - \\
300 & 130 & 0.990 & 353.2 & 0.0076 & 39.2 \\
$300+0.08 \mathrm{KBr}$ & 403.7 & 0.987 & 221.7 & 0.0024 & 68.4 \\
$300+0.08 \mathrm{KI}$ & 701.2 & 0.992 & 152.5 & 0.0014 & 81.6 \\
\hline
\end{tabular}

As can be seen from Table 4, halide ions a significant drop of mild steel corrosion rate. greatly enhance the inhibition efficiency of Similar observations have been reported Acacia senegal gum in acidic medium leading to elsewhere (El-Maksoud 2008, Umoren et al. 
2008, Shaju et al. 2012). Corrosion inhibition enhancement effect of the halides was greater for iodide ions compared to bromide ions (i.e. $\mathrm{I}^{-}$ $>\mathrm{Br}^{-}$) consistent with previous findings (Umoren et al. 2008).

The synergistic effects of halide ions in the presence of Acacia senegal gum were evaluated using the synergism parameter, $S_{1}$, by using the relationship initially given by Aramaki and Hacherman and reported elsewhere (Umoren et al. 2008). It has been well addressed that synergistic parameter approaches unity when there are no interactions between the inhibitors compounds whereas synergistic parameter greater than unity implies the existence of synergistic effect (Shaju et al. 2012). Synergism parameters for $\mathrm{KBr}$ and $\mathrm{KI}$ obtained from the inhibition efficiencies at $35{ }^{\circ} \mathrm{C}$ are shown (Table 5 ). The synergism values obtained are more than unity and the enhanced inhibition efficiency caused by the addition of halide ions to the Acacia senegal gum is in the order $\mathrm{Br}^{-}<\mathrm{I}^{-}$. Synergistic effects of halide ions on corrosion inhibition have also been reported (Umoren et al. 2008) where it was observed that the inhibition efficiency of Raphia hookeri gum on mild steel corrosion inhibition raised from $70 \%$ to $75.2 \%$ for $\mathrm{KI}$ and $70 \%$ to $73.4 \%$ for $\mathrm{KBr}$ at $30{ }^{\circ} \mathrm{C}$. In another study (Orubite-Okorosaye et al. 2007), it was observed that the corrosion inhibition efficiency of mild steel in $0.1 \mathrm{M}$ and $0.5 \mathrm{M} \mathrm{HCl}$ by Nypa fructicans's wurmb extract is higher in the presence of KI than pure extract of Nypa fruticans' wurmb. The inhibition efficiency was enhanced from $77.31 \%$ to $95.36 \%$ with the inclusion of $\mathrm{KI}$ at $30^{\circ} \mathrm{C}$.

Table 5: Synergism parameters $\left(S_{1}\right)$ for Acacia senegal gum with halide ions from electrochemical impedance spectroscopy and potentiodynamic polarization studies

\begin{tabular}{ccc}
\hline Halide & $S_{I}($ EIS $)$ & $S_{I}(\mathrm{PP})$ \\
\hline $\mathrm{KBr}$ & 1.85 & 2.38 \\
$\mathrm{KI}$ & 1.62 & 1.53 \\
\hline
\end{tabular}

Note: EIS $=$ Electrochemical Impedance Spectroscopy; $\mathrm{PP}=$ Potentiodynamic.

\section{Polarization}

Adsorption of organic inhibitors can be analyzed in terms of thermodynamics, i.e. adsorption equilibrium by applying the adsorption isotherms. Important information on the interactions between the inhibitor molecule and the metal surface can be provided from adsorption isotherms (Buchweishaija 1997). The most frequently used isotherms are Langmuir, Frumkin, Temkin and Freundlich (Buchweishaija 1997, Shaju et al. 2012). Among the adsorption isotherms mentioned above, the Langmuir adsorption isotherm was found to be suitable for the description of the adsorption of Acacia senegal gum on the mild steel electrodes in $0.5 \mathrm{M}$ sulfuric acid solution. The isotherm is described by the equation;

$$
\begin{gathered}
\frac{C}{\theta}=\frac{1}{K_{a d s}}+C_{i n h} \text { with } \\
\Delta G_{\text {ads }}^{0}=-R T \ln (K \times 55.5)
\end{gathered}
$$

where $\mathrm{C}_{\mathrm{inh}}$ is the inhibitor concentration, $K_{\mathrm{ads}}$ the adsorption equilibrium constant and $\Delta \mathrm{G}_{\text {ads }}^{0}$ the standard free energy of the adsorption (Shaju et al. 2012). A linear plot of $\mathrm{C} / \theta$ versus $\mathrm{C}_{\text {inh }}$ was observed. Figures 5 and 6 present the Langmuir adsorption isotherms from polarization and impedance data, respectively. The fit of the experimental data to this isotherm provides evidence of the role of adsorption in the observed corrosion inhibition effects of Acacia senegal gum. It has been argued (Ebenso et al. 2008, Eddy and Ebenso 2008, Shaju et al. 2012) that the values of $\Delta G_{\text {ads }}^{\circ}$ up to $-20 \mathrm{~kJ} / \mathrm{mol}$ are consistent with electrostatic interactions between charged molecules and a charged metal indicating physical adsorption. Values more negative than $-40 \mathrm{~kJ} / \mathrm{mol}$ involve charge sharing or transfer from the inhibitor molecules to the metal surface to form a coordinate type bond an indicative of chemisorption (Eddy and Ebenso 2008, Shaju et al. 2012). The obtained values of $K_{a d s}$ (Table 6) are low suggesting weak interactions (physisorption) of the active constituents found in Acacia senegal gum. The values of free energy of adsorption for Acacia senegal gum at $35{ }^{\circ} \mathrm{C}$ show that Acacia senegal gum is 
physically adsorbed on the metal surface. The value of $-11.05 \mathrm{~kJ} / \mathrm{mol}$ for Alizarian yellow GG (an azo dye) corrosion inhibitor at $30^{\circ} \mathrm{C}$ that indicates physical adsorption of the dye has been reported (Umoren et al. 2008, Eddy and Ebenso 2008).

Table 6: Thermodynamic parameters obtained from electrochemical investigation of mild steel in $0.5 \mathrm{M} \mathrm{H}_{2} \mathrm{SO}_{4}$ at $35{ }^{\circ} \mathrm{C}$ with Acacia senegal gum

\begin{tabular}{lccc}
\hline Technique & $K_{\text {ads }}$ & $R^{2}$ & $\Delta \mathrm{G}^{\circ}$ ads $(\mathrm{kJ} / \mathrm{mol})$ \\
\hline From polarization results & 1.4 & 0.937 & -11.14 \\
From impedance results & 25 & 0.989 & -18.52 \\
\hline
\end{tabular}

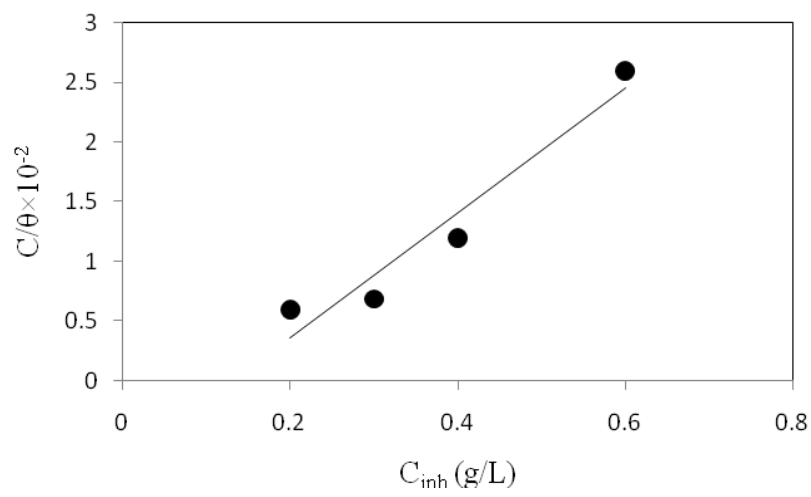

Figure 5: Langmuir adsorption isotherm for adsorption of Acacia senegal gum on mild steel surface in $0.5 \mathrm{M} \mathrm{H}_{2} \mathrm{SO}_{4}$ solution from polarization data at $35^{\circ} \mathrm{C}$.

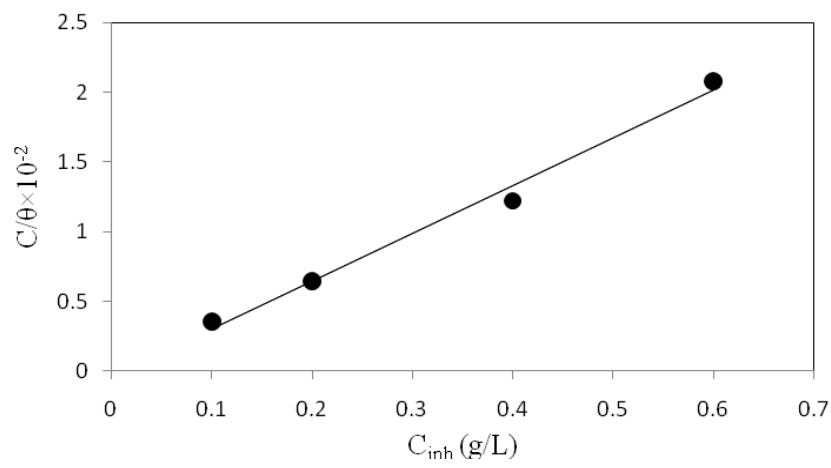

Figure 6: Langmuir adsorption isotherm for adsorption of Acacia senegal gum on mild steel surface in $0.5 \mathrm{M} \mathrm{H}_{2} \mathrm{SO}_{4}$ solution from impedance data at $35^{\circ} \mathrm{C}$.

\section{Conclusions}

The synergistic effects of halide ions on the corrosion inhibition of mild steel in sulfuric acid solution by Acacia senegal gum was studied. Results have shown that Acacia senegal gum exudate moderately inhibits mild steel corrosion in $0.5 \mathrm{M}$ sulfuric acid solution and its efficiency increases with concentrations up to an optimal concentration of $300 \mathrm{ppm}$, corresponding to the inhibition efficiency of $43.3 \%$, beyond which the efficiency declines. The results also show that addition of halide ions in Acacia senegal gum significantly enhance the inhibition efficiency due to synergism, with the inhibition efficiency up to $81.6 \%$. Notwithstanding, iodide ions have shown higher efficiency than bromide ions. The absorption of Accacia senegal gum obeys 
Langmuir's adsorption isotherm. The thermodynamic parameters calculated from the adsorption isotherms showed that physisorption was involved in the inhibition process.

Acknowledgement: The authors acknowledge Mkwawa University College of Education for supporting this study.

\section{References}

Abu-Dalo MA, Othman AA and AlRawashdeh NAF 2012 Exudate Gum from Acacia trees as green corrosion inhibitor for mild steel in acidic media. Int. $J$. Electrochem. Sci. 7: 9303-9324.

Al-Otaibi MS, Al-Mayouf AM, Khan M, Mousa AA, Al-Mazroa SA and Alkhathlan HZ 2014 Corrosion inhibitory action of some extracts on the corrosion of mild steel in acidic media. Arab. J. Chem. 7: 340-346.

Alsabagh AM, Migahed MA, Abdelraouf M and Khami EA 2015 Utilization of green tea as environmentally friendly corrosion inhibitor for carbon steel in acidic media. Int. J. Electrochem. Sci. 10: 1855-1872.

Buchweishaija J 1997 Inhibiting properties and adsorption of an amine based fatty acid corrosion inhibitor on carbon steel in aqueous carbon dioxide solution. $\mathrm{PhD}$ thesis, Norwegian University of Science and Technology.

Buchweishaija J and Mhinzi GS 2008 Natural products as a source of environmentally friendly corrosion inhibitors: The case of gum exudate from Acacia seyal var. seyal. Port. Electrochim. Acta 26: 257-265.

Chaudhary RS, Tyagi DK and Kumar A 2007 Corrosion inhibition of mild steel in hydrochlolic acid by acyl compound. J. Sci. Ind. Res. 66: 835-840.

Ebenso EE, Eddy NO and Odiongenyi AO 2008 Corrosion inhibitive properties and adsorption behaviour of ethanol extract of Piper guinensis as a green corrosion inhibitor for mild steel in $\mathrm{H}_{2} \mathrm{SO}_{4}$. Afr. J. Pure Appl. Chem. 2(11): 107-115.

Eddy NO and Ebenso EE 2008 Adsorption and inhibitive properties of ethanol extracts of
Musa sapientum peels as a green corrosion inhibitor for mild steel in $\mathrm{H}_{2} \mathrm{SO}_{4}$. Afr. J. Pure Appl. Chem. 2: 046-054.

Eddy NO 2009a Ethanol extract of Phyllanthus amarus as a green inhibitor for the corrosion of mild steel in $\mathrm{H}_{2} \mathrm{SO}_{4}$. Port. Electrochim. Acta 27(5): 579-589.

Eddy NO 2009b Inhibitive and adsorption properties of ethanol extract of Colocasia esculenta leaves for the corrosion of mild steel in $\mathrm{H}_{2} \mathrm{SO}_{4}$. Int. J. Phys. Sci. 4(4): 165171.

El-Etre AY and El-Tantawy Z 2006 Inhibition of metallic corrotion using ficus extract. Port. Electrochem. Acta 24: 347-356.

El-Maksoud SAA 2008 The effect of organic compounds on the electrochemical behaviour of steel in acidic media. A review. Int. J. Electrochem. Sci. 3: 528-555.

Gupta DK and Jinendra S 2009 Corrosion inhibitive properties of different plant extract. Arch. Appl. Sci. Res. 1(1): 51-56.

Khan G, Kazi MSN, Wan JB, Hapipah BMA, Fadhil LF and Ghulam MK 2015 Application of natural product extracts as green corrosion inhibitors for metals and alloys in acid pickling processes: A review. Int. J. Electrochem. Sci. 10: 6120-6134.

Kulandai Therese S and Vasudha VG 2015 Thermodynamic and adsorption studies for corrosion inhibition of mild steel using millingtonia hortensis. Int. J. Inf. Res. Rev. 2: 261-266.

Martinez S and Stern I 2002 Thermodynamic characterization of metal dissolution and inhibitors adsorption processes in the low carbon steel/ mimosa tannin/sulfuric acid system. Appl. Surf. Sci. 199: 83-89.

Noor EA 2007 Temperature effects on the corrosion inhibition of mild steel in acidic solutions by aqueous extract of Fenugreek leaves. Int. J. Electrochem. Sci. 2: 9961017.

Obot IB, Ebenso EE and Gasem ZM 2012 Ecofriendly corrosion inhibitors: adsorption and inhibitive action of ethanol extracts of Chlomolaena odorata $L$. for the corrosion 
of mild steel in $\mathrm{H}_{2} \mathrm{SO}_{4}$ solutions. Int. J. Electrochem. Sci. 7: 1997-2008.

Obot IB 2009 Synergistic effect of nizoral and iodide ions on the corrosion inhibition of mild steel in sulphuric acid solution. Port. Electrochim. Acta 27(5): 539-553.

Odiongenyi AO, Odoemelam SA and Eddy NO 2009 Corrosion inhibition and adsorption properties of ethanol extract of Vernonia amygdalina for the corrosion of mild steel in $\mathrm{H}_{2} \mathrm{SO}_{4}$. Port. Electrochim. Acta 27: 3345.

Oguzie EE 2008 Corrosion inhibitive effect and adsorption behaviour of Hibiscus sabdariffa extract on mild steel in acidic media. Port. Electrochim. Acta 26: 303314.

Olusegun AK, Oforka NC and Ebenso EE 2004 The inhibition of mild ateel corrosion in an acidic medium by the juice of Citrus paradisi (grapefruit). J. Corros. Sci. Eng. 8: $1-5$.

Orubite-Okorosaye K, Jack IR, Ochei M and Akaranta O 2007 Synergistic effect of potassium iodide on corrosion inhibition of mild steel in $\mathrm{HCl}$ medium by extracts of Nypa fruticans' Wurmb. J. Appl. Sci. Environ. Manage 11(2): 27-31.

Shaju KS, Thomas KJ, Raphael VP and Paul A 2012 Synergistic effect of KI on corrosion inhibition of mild steel by polynuclear schiff base in sulphuric acid. Int. Schol. Res. Netw. 2012.

Umoren SA, Obot IB, Ebenso EE and ObiEgbedi NO 2008 Synergistic inhibition between naturally occurring exudate gum and halide ions on the corrosion of mild steel in acidic medium. Int. J. Electrochem. Sci. 3: 1029-1043. 